\title{
Chemical Composition and Energy Yield of Elephant-Grass Biomass as Function of Five Different Production Ages
}

\author{
Rafael Souza Freitas ${ }^{1}$, Tatiane da Costa Barbé ${ }^{1}$, Rogério Figueiredo Daher ${ }^{1}$, Ana Kesia Faria Vidal ${ }^{1}$, \\ Wanessa Francesconi Stida ${ }^{1}$, Veronica Brito da Silva ${ }^{1}$, Bruna Rafaela da Silva Menezes ${ }^{2}$ \\ \& Antônio Vander Pereira ${ }^{3}$ \\ ${ }^{1}$ Universidade Estadual do Norte Fluminense Darcy Ribeiro, Campos dos Goytacazes, RJ, Brazil \\ ${ }^{2}$ Universidade Federal Rural do Rio de Janeiro, Seropédica, RJ, Brazil \\ ${ }^{3}$ Embrapa Gado de Leite, Rua Eugênio do Nascimento, Juiz de Fora, MG, Brazil \\ Correspondence: Rafael Souza Freitas, Universidade Estadual do Norte Fluminense Darcy Ribeiro, CEP: \\ 28013-602, Campos dos Goytacazes, RJ, Brazil. Email: rafael.mutum@hotmail.com
}

Received: October 18, 2017

Accepted: November 12, 2017

Online Published: December 15, 2017

doi:10.5539/jas.v10n1p343

URL: https://doi.org/10.5539/jas.v10n1p343

\begin{abstract}
Elephant grass has high biomass production, with qualities suitable for conversion into bioenergy, but has long been used exclusively for animal feed and only in recent years has it become an energetic alternative. Therefore, it is necessary to select genotypes with potential for energy production. This study evaluated the effect of five harvest times $(8,12,16,20$, and 24 weeks) on the yield and chemical composition related to biomass quality through combined polynomial regression analyses of the following elephant grass genotypes: Cubano Pinda, Mercker 86-México, Pusa Napier n ${ }^{\circ}$, Mole de Volta Grande, P-241-Piracicaba, and King Grass. A completely randomized design with three replicates, in a split-plot arrangement, was adopted, including two factors (plots = genotypes, subplots $=$ harvest times). The evaluated variables were whole-plant dry matter yield, in $\mathrm{t} \mathrm{ha}^{-1}$ (DMY), percentage of neutral detergent fiber (\%NDF), and percentage of acid detergent fiber (\%ADF). The elephant-grass genotypes Cubano de Pinda, Mercker 86-México, and P-241-Piracicaba showed a linear first-degree effect as a function of the harvest intervals, indicating that they did not reach their maximum production potential. Genotypes Pusa Napier $\mathrm{n}^{\circ}$, Mole de Volta Grande, and King Grass, in turn, had a linear second-degree effect. For the NDF variable, all genotypes showed a significant linear second-degree effect as a function of the harvest intervals, except P-241-Piracicaba, for which no regression was observed. For this genotype, there was a significant linear first-degree effect on the \%ADF variable.
\end{abstract}

Keywords: Pennisetum purpureum Schum, linear regression, bioenergy, biomass quality

\section{Introduction}

As a consequence of the oil crisis, the energy system had to be reorganized into more solid and sustainable bases, which is one of the great challenges of research, since, in addition to being finite, the energy derived from oil contributes to the greenhouse gas effect, which threatens the earth's climate balance (Scarlat et al., 2011).

The biomass is a prominent alternative renewable-energy source. Because its production recycles the atmospheric $\mathrm{CO}_{2}$ through photosynthetic processes, it is one of the safest energy alternatives (Schemer et al., 2008).

This scenario indicates a need for the development of technologies able to convert the biomass of plants into chemical products, energy, and other materials that may be fundamental to move the world economy towards a renewable and sustainable energy matrix (Fontoura et al., 2015).

Today, the energy derived from biomass is estimated to account for $14 \%$ of the entire global consumption of primary energy. In some developing countries, this figure may jump to $34 \%$, reaching $60 \%$ in Africa (IPCC, 2011), suggesting that, in the long term, biomass will be one of the most efficient energy alternatives (Kalt \& Kranzl, 2011). 
Elephant grass has stood out as one of the main forage species used for this purpose (Morais et al., 2011) because of its high production of biomass with suitable quality for conversion into bioenergy (Mohammed et al., 2015). This species is highly efficient in fixing atmospheric $\mathrm{CO}_{2}$ (carbon dioxide) during its photosynthesis process.

For a long time, elephant grass was used exclusively in animal feeding, and only in recent years has it become an energy source. This has changed the desirable characteristics in the chemical composition of this species, since, now, a plant high in fiber, coupled with high biomass yields, is sought (Morais et al., 2009).

The importance of knowing the ideal age for harvest has been stressed by many researchers aiming at improved animal production, but little information is available for energy purposes. In this way, studies should be carried out with specific elephant-grass genotypes for biomass production for energy generation. The aim of the present study was to evaluate the effect of five harvest times $(8,12,16,20$ and 24 weeks) on the yield and chemical composition related to the biomass quality of six genotypes of elephant grass through combined polynomial regression analyses so that one can determine the ideal age of cutting the elephant grass for energetic purposes.

\section{Material and methods}

The experiment was implemented on April 26, 2010, at the State Center for Research in Agroenergy and Waste Utilization of PESAGRO, located in Campos dos Goytacazes, RJ, Brazil. According to the Köppen (1948) classification, the climate of the region is a hot tropical and humid Aw type with dry winters and rainy summers.

The soil of the experimental area is classified as a Typic Dystrophic Yellow Latosol (EMBRAPA, 2006) with the following chemical composition: $\mathrm{pH}-6.3$, phosphorus $-5.0 \mathrm{mg} \mathrm{dm}^{-3}$, potassium $-176 \mathrm{mg} \mathrm{dm}^{-3}$, calcium - 2.6 $\mathrm{cmol}_{\mathrm{c}} \mathrm{dm}^{-3}$, magnesium $-1.4 \mathrm{cmol}_{\mathrm{c}} \mathrm{dm}^{-3}$, aluminum $-0.1 \mathrm{cmol}_{\mathrm{c}} \mathrm{dm}^{-3}$, hydrogen + aluminum $-0.0 \mathrm{cmol}_{\mathrm{c}} \mathrm{dm}^{-3}$, and carbon $-1.26 \%$.

The six most productive genotypes with best biomass quality were selected and evaluated according to the results obtained by Rossi et al. (2014), as follows: Cubano Pinda, Mercker 86-México, Pusa Napier n¹, Mole de Volta Grande, P-241-Piracicaba, and King Grass.

A randomized block design with three replicates, in a split-plot arrangement, was adopted, including two factors (plots $=$ genotypes, subplots $=$ harvest times). Each plot consisted of a $15-\mathrm{m}$ row spaced $1 \mathrm{~m}$ apart from each other, while each subplot consisted of $3 \mathrm{~m}$, considering only the two central meters in the row for evaluation and disregarding half a meter from the extremities of each plot.

After the stage of establishment in the field, the first uniformity cut was made on August 5, 2010, followed by topdressing with $30 \mathrm{~kg} \mathrm{ha}^{-1}$ ammonium sulfate and $20 \mathrm{~kg} \mathrm{ha}^{-1}$ potassium chloride. Seedlings were replanted to recompose the plots, followed by equal topdressing, on October 31, 2010. After this procedure to reestablish the crop in the field, another uniformity cut was made on December 10. From that date, plots chosen at random were harvested, at 8,12, 16, 20, and 24 weeks of age, on 02/02/2011,03/02/2011, 04/05/2011, 04/26/2011, and $05 / 23 / 2011$, respectively.

After the harvest, the traits were evaluated in samples of whole plants collected at random.

Before being analyzed and evaluated in a laboratory, these samples were dried in a forced-air oven at $65{ }^{\circ} \mathrm{C}$ for $72 \mathrm{~h}$. After drying, samples were ground through a Wiley mill with 1-mm sieves and placed in glass jars.

The following biomass quality traits were evaluated:

Dry matter yield, in $\mathrm{t} \mathrm{ha}^{-1}$ (DMY), was estimated as the total production of green matter by the whole plant by the percentage of dry matter of the whole plant, and the obtained value was converted to $t \mathrm{ha}^{-1}$.

Chemical composition: percentage of neutral detergent fiber (\%NDF) and percentage of acid detergent fiber (\%ADF), analyzed in the Laboratory of Food Analysis of Embrapa Dairy Cattle, in Juiz de Fora, MG, Brazil, by the near infrared spectroscopy (NIRS) method, using a Perstorp 5000 analytical spectrometer (Silver Spring, MD) coupled to a microcomputer equipped with the ISI software version 4.1 (Infrasoft International, University, Park, PA). Preliminary evaluations were carried out for the calibration of the equipment, using samples corresponding to the different harvest ages. The definitive reading was made using the wavelengths of 1100 to $2500 \mathrm{~nm}$.

Statistical analyses were performed using the Genes software (Cruz, 2013), developed by the Federal University of Viçosa.

\section{Results and Discussion}

\subsection{Dry Matter Yield (DMY)}

Based on the estimates of mean squares for the sources of variation, regression, and deviations from regression for the linear first- and second-degree models applied to the mean values of dry matter yield (DMY) involving 
six genotypes of elephant grass in the five harvests during the experiment (Table 1), a significant linear effect of harvest intervals was observed on the genotypes.

Table 1. Estimates of mean squares for the sources of variation due to regression and deviations from regression for the linear first- and second-degree models for dry matter yield (DMY) in six elephant-grass genotypes

\begin{tabular}{|c|c|c|c|c|c|c|c|c|}
\hline \multirow{2}{*}{ Genotypes } & \multirow{2}{*}{ SV } & \multicolumn{7}{|c|}{ MS } \\
\hline & & DF & $1^{\circ}$ Degree & $\mathrm{R}^{2}(\%)$ & GL & $2^{\circ}$ Degree & $\mathrm{R}^{2}(\%)$ & Model \\
\hline \multirow[t]{2}{*}{ Cubano Pinda } & Reg & 1 & $320.48 * *$ & 90,05 & 2 & $0.40^{\text {ns }}$ & 90,17 & 1 \\
\hline & Deviations & 3 & $11.79 *$ & & 2 & $17.48^{\mathrm{ns}}$ & & \\
\hline \multirow[t]{2}{*}{ Mercker 86-México } & Reg & 1 & $840.83 * *$ & 97,08 & 2 & $7.35^{\mathrm{ns}}$ & 97,93 & 1 \\
\hline & Deviations & 3 & $8.44^{\mathrm{ns}}$ & & 2 & $8.99^{\mathrm{ns}}$ & & \\
\hline \multirow[t]{2}{*}{ Pusa Napier $n^{\circ} 1$} & Reg & 1 & $318.21 * *$ & 57,11 & 2 & $230.78^{* *}$ & 98,53 & 2 \\
\hline & Deviations & 3 & $79.65^{\text {ns }}$ & & 2 & $4.09^{\mathrm{ns}}$ & & \\
\hline \multirow[t]{2}{*}{ Mole de Volta Grande } & Reg & 1 & $408.96 * *$ & 71,78 & 2 & $113.59 * *$ & 91,72 & 2 \\
\hline & Deviations & 3 & $56.57 * *$ & & 2 & $23.56^{*}$ & & \\
\hline \multirow[t]{2}{*}{ P-241-Piracicaba } & Reg & 1 & $538.93 * *$ & 92,59 & 2 & $0.11^{\mathrm{ns}}$ & 92,62 & 1 \\
\hline & Deviations & 3 & $14.38^{\mathrm{ns}}$ & & 2 & $25.51^{\mathrm{ns}}$ & & \\
\hline \multirow[t]{2}{*}{ King Grass } & Reg & 1 & $439.51 * *$ & 52,17 & 2 & $116.34 * *$ & 65,99 & 2 \\
\hline & Deviations & 3 & $134.25^{* *}$ & & 2 & $143.20 * *$ & & \\
\hline
\end{tabular}

Note. ${ }^{* *}=$ Significant at the $1 \%$ probability level by the $\mathrm{F}$ test, $*=$ Significant at the $5 \%$ probability level by the $\mathrm{F}$ test, ns $=$ Not significant.

Genotypes Cubano Pinda, Mercker 86-México, and P-241-Piracicaba showed a linear first-degree effect ( $\mathrm{p}<$ $0.01)$. Genotypes Pusa Napier $n^{\circ} 1$, Mole de Volta Grande, and King Grass, in turn, had a linear second-degree effect $(\mathrm{p}<0.01)$.

The elevated biomass production capacity is one of the most important traits to be evaluated in this crop (Morais et al., 2011). In the current experimental conditions, comparing the dry matter yield of 12 weeks to that obtained at eight weeks (Table 2), increases of 66\% (Mole de Volta Grande and Cubano de Pinda) to 290\% (King Grass) were observed. Values close to the mean (136\%) were found in Mercker 86-México (107\%), Pusa Napier $n^{\circ} 1$ (129\%), and P-241-Piracicaba (161\%).

Table 2. Dry matter yield $\left(\mathrm{t} \mathrm{ha}^{-1}\right)$ of six genotypes of elephant grass at five harvest times

\begin{tabular}{llllll}
\hline \multirow{2}{*}{ Genotypes } & \multicolumn{5}{c}{ Production Ages (weeks) } \\
\cline { 2 - 6 } & 8 & 12 & 16 & 20 & 24 \\
\hline Cubano Pinda & 7.23 & 12.08 & 15.29 & 14.82 & 22.21 \\
Mercker 86-México & 6.25 & 12.97 & 15.37 & 20.66 & 28.87 \\
Pusa Napier n $^{\circ} 1$ & 7.27 & 16.69 & 24.18 & 23.05 & 20.37 \\
Mole de Volta Grande & 6.81 & 11.31 & 19.97 & 23.62 & 19.11 \\
P-241-Piracicaba & 5.26 & 13.75 & 14.49 & 17.63 & 24.51 \\
King Grass & 6.80 & 26.54 & 21.13 & 23.25 & 27.58 \\
\hline
\end{tabular}

The observed dry matter contents confirm the increase in DM when the harvest interval is increased. Similar results were also observed by Quitete (2011) in an evaluation of elephant-grass hybrids in Campos dos Goytacazes, RJ, Brazil, and by Magalhães et al. (2006), who evaluated the forage yield of elephant grass in Parnaíba, CE, Brazil.

The high precipitation followed by high temperatures and light intensity in the region during the months preceding the harvest (Table 3) contributed to this increase in DM, since, according to Teixeira Vitor et al. (2009), low light intensity associated with temperatures below $15^{\circ} \mathrm{C}$ limits production in elephant grass genotypes. 
Table 3. Monthly precipitation recorded in the period of April 2010 to Mai 2010 in Campos dos Goytacazes, RJ, Brazil

\begin{tabular}{lll}
\hline \multirow{2}{*}{ Month } & \multicolumn{1}{c}{ Precipitation $(\mathrm{mm})$} \\
\cline { 2 - 3 } & 2010 & 2011 \\
\hline January & - & 115,6 \\
February & - & 0,5 \\
March & - & 211,5 \\
April & 61,5 & 25,4 \\
May & 25,9 & 41,0 \\
June & 24,5 & 12,2 \\
July & 57,5 & 7,20 \\
August & 2,3 & - \\
September & 7,5 & - \\
October & 87,8 & - \\
November & 88,8 & - \\
December & 69,8 & - \\
Total & 424,88 & 413,40 \\
\hline
\end{tabular}

Source: Meteorological Station of the State Center for Research in Agroenergy and Waste Utilization, Campos dos Goytacazes, RJ, Brazil.

With the favorable soil-climatic conditions in the region, i.e., the increased rainfall and higher temperatures during the experimental period, elephant grass can develop more easily, because such conditions, according to Silva et al. (2010), are near the ideal setting for the growth of this grass.

The regression analysis also revealed that the genotypes that responded with a linear first-degree model (Cubano de Pinda, Mercker 86-México, and P-241-Piracicaba) showed accumulation of DM during the entire production cycle at 24 weeks of age. These findings were not observed for genotypes Pusa Napier $\mathrm{n}^{\circ} 1$, King Grass, and Mole de Volta Grande, which showed maximum DMY of 24.14, 26.58, and $21.55 \mathrm{t} \mathrm{ha}^{-1}$ at $18.78,20.59$, and 21.51 weeks, respectively.

Sales et al. (2015) evaluated the yield of elephant grass in the state of Paraná, Brazil, aiming at energy generation, and observed that this variable rose up to 17 th week of age of the plants, but at values lower than that found in our study.

Other studies in which the authors investigated the harvest age of elephant grass on the yield of this forage also revealed increments in dry matter as the harvest intervals were increased (Queiroz Filho et al., 2000, Leite et al., 2000).

After these periods, there was a decline in DMY, which can be explained by the flowering period of the crop, since the harvests occurred between April and May. This indicates that the dry matter yield of elephant grass is affected not only by the age of the plant, but also by its flowering period (Figures 1 and 2). 


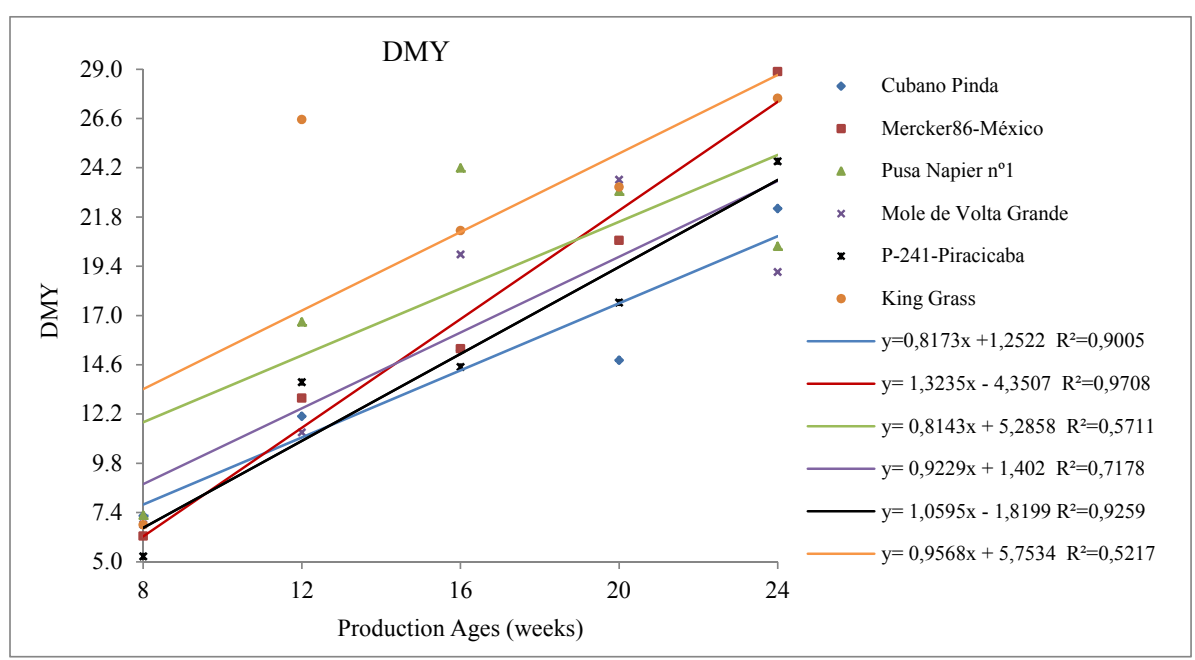

Figure 1. Lines adjusted for dry matter yield (DMY) obtained at five harvest times in genotypes Cubano Pinda (1), Mercker 86-México (2), Pusa Napier n ${ }^{\circ}$ (3), Mole de Volta Grande (4), P-241-Piracicaba (5), and King Grass (6)

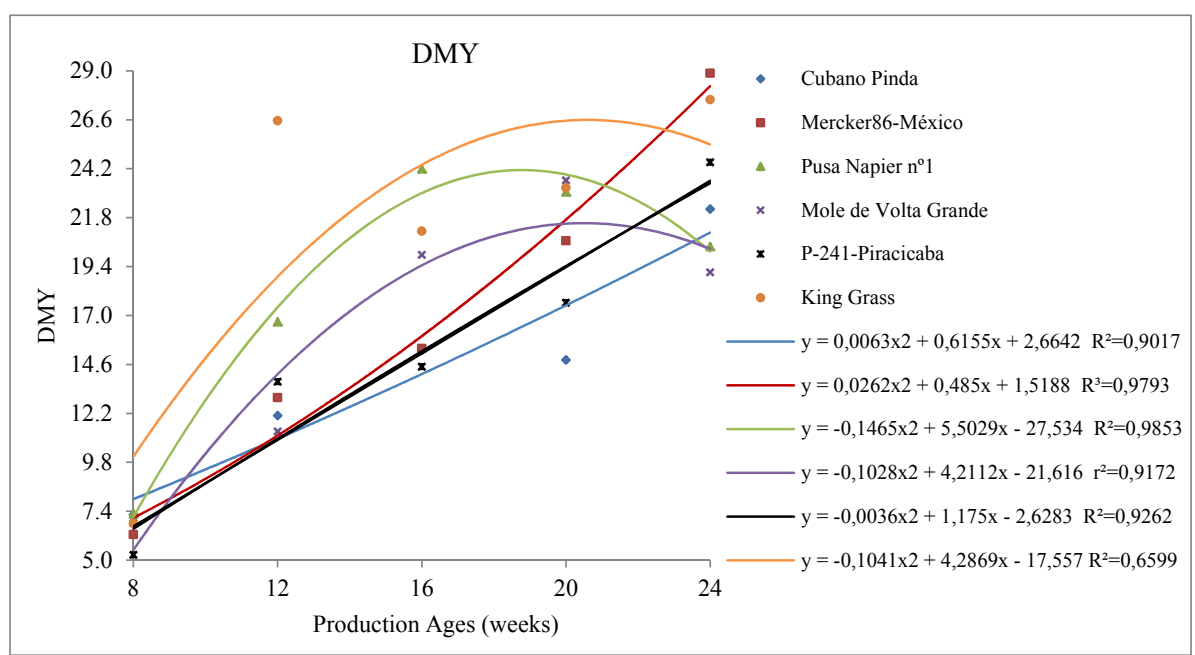

Figure 2. Curves adjusted for dry matter yield (DMY) obtained at five harvest times in genotypes Cubano Pinda (1), Mercker 86-México (2), Pusa Napier n ${ }^{\circ} 1$ (3), Mole de Volta Grande (4), P-241-Piracicaba (5), and King Grass (6)

\subsection{Percentages of Neutral (NDF) and Acid (ADF) Detergent Fiber}

According to Table 4 and Table 5, the estimates of mean squares for the sources of variation, regressions, and deviations for the linear first- and second-degree models applied to the mean NDF and ADF values of the six elephant-grass genotypes at five harvests performed throughout the experiment. For the NDF variable, all genotypes showed a linear second-degree effect as a function of harvest time (Table 4), except genotype P-241-Piracicaba, which showed no regression.

Also for genotype P-241-Piracicaba, a significant linear, first-degree effect was observed for the ADF variable (Table 5), whereas the Cubano de Pinda, Mercker 86-México, Pusa Napier $n^{\circ} 1$, Mole de Volta Grande, and King Grass genotypes showed a linear second-degree effect. 
Table 4. Estimates of mean squares for the sources of variation due to regression and deviations from regression for the linear first- and second-degree models for neutral detergent fiber (NDF) in six elephant-grass genotypes

\begin{tabular}{|c|c|c|c|c|c|c|c|c|}
\hline \multirow{2}{*}{ Genotypes } & \multirow{2}{*}{ SV } & \multicolumn{7}{|c|}{ MS } \\
\hline & & DF & $1^{\circ}$ Degree & $\mathrm{R}^{2}(\%)$ & GL & $2^{\circ}$ Degree & $\mathrm{R}^{2}(\%)$ & Model \\
\hline \multirow[t]{2}{*}{ Cubano Pinda } & Reg & 1 & $29.9029 * *$ & 18,33 & 2 & $44.9616^{* *}$ & 58,28 & 2 \\
\hline & Deviations & 3 & $43.2134 * *$ & & 2 & $43.5688 * *$ & & \\
\hline \multirow[t]{2}{*}{ Mercker 86-México } & Reg & 1 & $77.9047 * *$ & 44,69 & 2 & $62.6890 * *$ & 81,34 & 2 \\
\hline & Deviations & 3 & $31.6501 * *$ & & 2 & $16.1306^{* *}$ & & \\
\hline \multirow[t]{2}{*}{ Pusa Napier $n^{\circ} 1$} & Reg & 1 & $15.4937^{\mathrm{ns}}$ & 6,33 & 2 & $53.7301 * *$ & 29,48 & 2 \\
\hline & Deviations & 3 & $73.1065 * *$ & & 2 & $82.7448 * *$ & & \\
\hline \multirow[t]{2}{*}{ Mole de Volta Grande } & Reg & 1 & $73.6038^{* *}$ & 47,77 & 2 & $26.3438 * *$ & 78,64 & 2 \\
\hline & Deviations & 3 & $26.3491 * *$ & & 2 & $9.2494 * *$ & & \\
\hline \multirow[t]{2}{*}{ P-241-Piracicaba } & Reg & 1 & $8.8073^{\mathrm{ns}}$ & 8,36 & 2 & $14.6273^{\mathrm{ns}}$ & 33,33 & Absence \\
\hline & Deviations & 3 & $29.6010 * *$ & & 2 & $44.9454 * *$ & & \\
\hline \multirow[t]{2}{*}{ Kiing Grass } & Reg & 1 & $17.4538^{\mathrm{ns}-}$ & 11,27 & 2 & $56.1169^{* *}$ & 49,35 & 2 \\
\hline & Deviations & 3 & $43.87 .71 * *$ & & 2 & 37.7573 & & \\
\hline
\end{tabular}

Note. $* *=$ Significant at the $1 \%$ probability level by the $\mathrm{F}$ test, $*=$ Significant at the $5 \%$ probability level by the $\mathrm{F}$ test, $\mathrm{ns}=$ Not significant.

Table 5. Estimates of mean squares for the sources of variation due to regression and deviations from regression for the linear first- and second-degree models for acid detergent fiber (ADF) in six elephant-grass genotypes

\begin{tabular}{|c|c|c|c|c|c|c|c|c|}
\hline \multirow{2}{*}{ Genotypes } & \multirow{2}{*}{ SV } & \multicolumn{7}{|c|}{ MS } \\
\hline & & DF & $1^{\circ}$ Degree & $\mathrm{R}^{2}(\%)$ & GL & $2^{\circ}$ Degree & $\mathrm{R}^{2}(\%)$ & Model \\
\hline \multirow[t]{2}{*}{ Cubano Pinda } & Reg & 1 & $91.7519 * *$ & 43,77 & 2 & $43.4701 * *$ & 64,67 & 2 \\
\hline & Desvio & 3 & $39.1101 * *$ & & 2 & $36.9300 * *$ & & \\
\hline \multirow[t]{2}{*}{ Mercker 86-México } & Reg & 1 & $158.8001^{* *}$ & 60,7 & 2 & $52.3795 * *$ & 80,84 & 2 \\
\hline & Desvio & 3 & $34.1425 * *$ & & 2 & $25.0241 * *$ & & \\
\hline \multirow[t]{2}{*}{ Pusa Napier $n^{\circ} 1$} & Reg & 1 & $48.8325 * *$ & 18,52 & 2 & $43.2153^{* *}$ & 35,06 & 2 \\
\hline & Desvio & 3 & $71.2407 * *$ & & 2 & $85.2535 * *$ & & \\
\hline \multirow[t]{2}{*}{ Mole de Volta Grande } & Reg & 1 & $135.1250 * *$ & 61,51 & 2 & $36.9546^{* *}$ & 78,48 & 2 \\
\hline & Desvio & 3 & $28.0490 * *$ & & 2 & 23.5963 & & \\
\hline \multirow[t]{2}{*}{ P-241-Piracicaba } & Reg & 1 & $55.1903 * *$ & 34,42 & 2 & $14.6273 \mathrm{~ns}$ & 43,72 & 1 \\
\hline & Desvio & 3 & $34.8394 * *$ & & 2 & $44.9454 * *$ & & \\
\hline \multirow[t]{2}{*}{ Kiing Grass } & Reg & 1 & $27.1013^{* *}$ & 13,22 & 2 & $53.3722 * *$ & 39,6 & 2 \\
\hline & Desvio & 3 & $58.6966^{* *}$ & & 2 & $61.3588^{* *}$ & & \\
\hline
\end{tabular}

Note. $* *=$ Significant at the $1 \%$ probability level by the $\mathrm{F}$ test, $*=$ Significant at the $5 \%$ probability level by the $\mathrm{F}$ test, $\mathrm{ns}=$ Not significant.

As shown in Table 6 and Table 7, the NDF and ADF contents increased up to the 12th week of age, except in genotype Mercker 86-México, which had these components increased until the 16th week. Genotype Mole de Volta Grande exhibited the highest NDF content, which was $79.41 \%$ at 24 weeks of age.

According to Martins-Costa et al. (2008), if this genotype shows the best results for this trait, it can also be expected to have the best contents of cellulose and lignin. 
Table 6. Neutral detergent fiber (NDF) content of six elephant-grass genotypes evaluated at different harvest ages

\begin{tabular}{llllll}
\hline \multirow{2}{*}{ Genotypes } & \multicolumn{5}{c}{ Production Ages (weeks) } \\
\cline { 2 - 6 } & 8 & 12 & 16 & 20 & 24 \\
\hline Cubano Pinda & 69.98 & 79.9 & 77.07 & 76.45 & 76.64 \\
Mercker 86-México & 69.06 & 77.6 & 78.07 & 76.67 & 77.55 \\
Pusa Napier n ${ }^{\circ}$ 1 & 68.03 & 79.58 & 75.9 & 71.64 & 75.52 \\
Mole de Volta Grande & 71.37 & 79.8 & 78.65 & 79.29 & 79.41 \\
P-241-Piracicaba & 71.09 & 78.95 & 75.72 & 74.39 & 75.98 \\
King Grass & 70.28 & 80.03 & 76.86 & 75.58 & 76.24 \\
\hline
\end{tabular}

Table 7. Acid detergent fiber (NDF) content of six elephant-grass genotypes evaluated at different harvest ages

\begin{tabular}{llllll}
\hline \multirow{2}{*}{ Genotypes } & \multicolumn{5}{l}{ Production Ages (weeks) } \\
\cline { 2 - 6 } & 8 & 12 & 16 & 20 & 24 \\
\hline Cubano Pinda & 37.22 & 47.59 & 44.55 & 45.77 & 46.87 \\
Mercker 86-México & 37.23 & 47.13 & 47.16 & 46.64 & 48.97 \\
Pusa Napier n ${ }^{\circ} 1$ & 36.38 & 48.78 & 44.11 & 42.13 & 46.07 \\
Mole de Volta Grande & 39.23 & 48.61 & 46.82 & 48.83 & 49.72 \\
P-241-Piracicaba & 37.86 & 47.06 & 43.26 & 43.39 & 46.46 \\
King Grass & 39.04 & 50.44 & 45.86 & 44.86 & 46.56 \\
\hline
\end{tabular}

The results found in this study are higher than those reported by Flores et al. (2013), who evaluated the NDF content in genotypes of elephant grass and found mean values ranging from 69 to $58 \%$, at 25 weeks of age. As stated by Mistura et al. (2007), these high values might have been a result of favorable soil-climatic factors during the period under evaluation (Table 3), which promoted greater growth and development of the elephant-grass tillers.

The regression analysis also showed that, for the NDF and ADF traits, the genotypes had a reduction in their fiber contents, since all of the evaluated genotypes had their maxima ranging between 17 and 19 weeks of age. Genotype Mole de Volta Grande obtained the highest percentage of NDF $-80.40 \%$, at 19 weeks of age (Figures 3 and 4).

Genotypes Pusa Napier $n^{\circ} 1$ and King Grass had the highest losses in NDF content, which decreased by $6 \%$ from the 12th to the 20th week. Similar results were found by Pereira et al. (2002), who studied genotypes of elephant grass and also found a decline in this variable after 75 to 90 days of age.

As depicted in Figures 5 and 6, the evaluated genotypes showed an increase in fiber content as they aged, which may be attributed to the thickening and lignification of the plant cell wall and mainly to the increased proportion of stems in the harvested material, as stated by Bhering et al. (2008).

The points of maximum obtained for the ADF variable in the evaluated genotypes occurred between 17 and 20 weeks, The maximum ADF attained by genotypes Cubano Pinda, Mercker 86-México, Pusa Napier $n^{\circ} 1$, Mole de Volta Grande, P-241-Piracicaba, and King Grass were 47.21, 48.79, 45.91, 49.74, 45.55, and 47.82\%, respectively. 


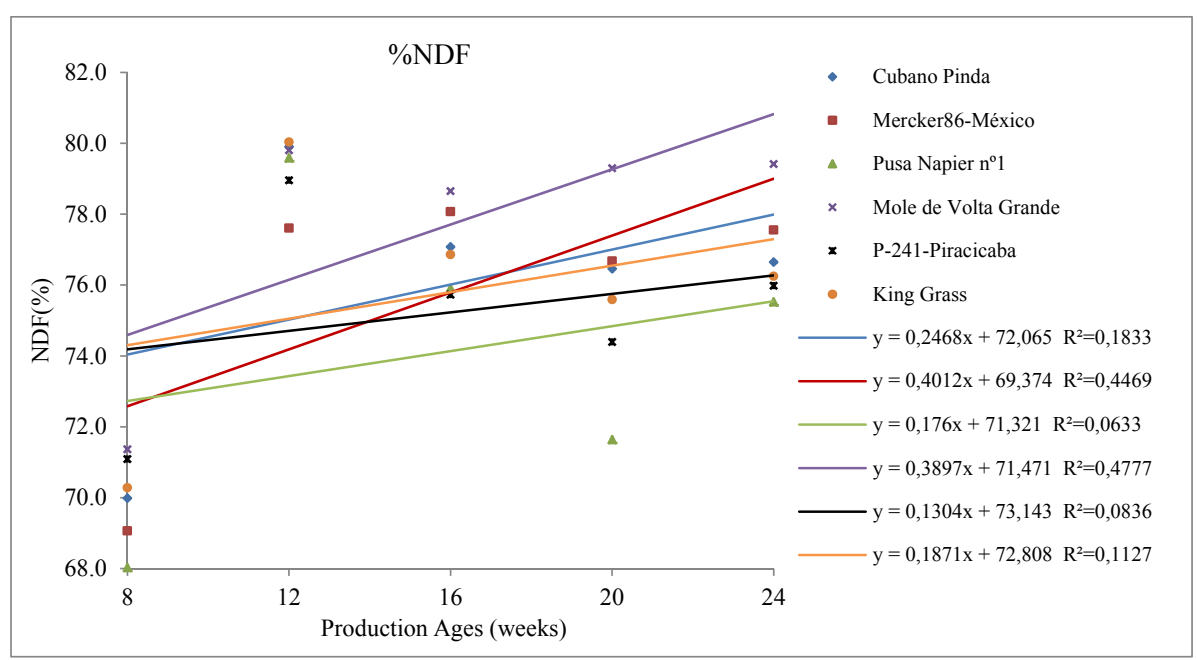

Figure 3. Lines adjusted for neutral detergent fiber (NDF) obtained at five harvest times in genotypes Cubano Pinda (1), Mercker 86-México (2), Pusa Napier n ${ }^{\circ} 1$ (3), Mole de Volta Grande (4), P-241-Piracicaba (5), and King Grass (6)

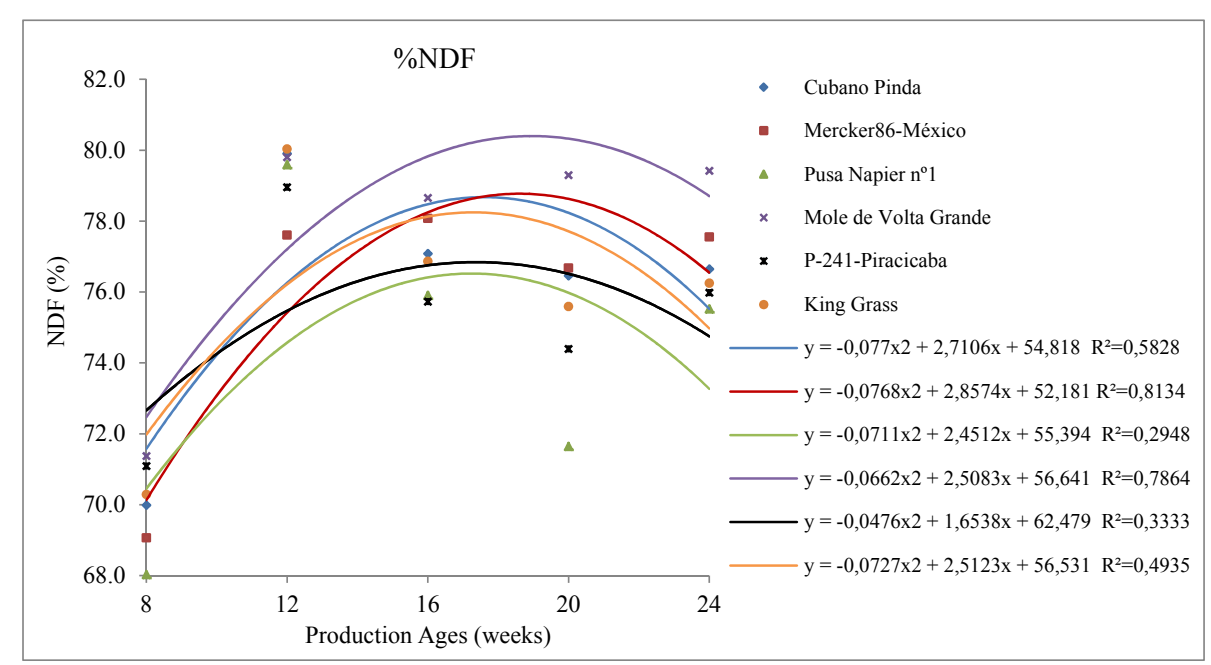

Figure 4. Curves adjusted for neutral detergent fiber (NDF) obtained at five harvest times in genotypes Cubano Pinda (1), Mercker 86-México (2), Pusa Napier nº 1 (3), Mole de Volta Grande (4), P-241-Piracicaba (5), and King Grass (6) 


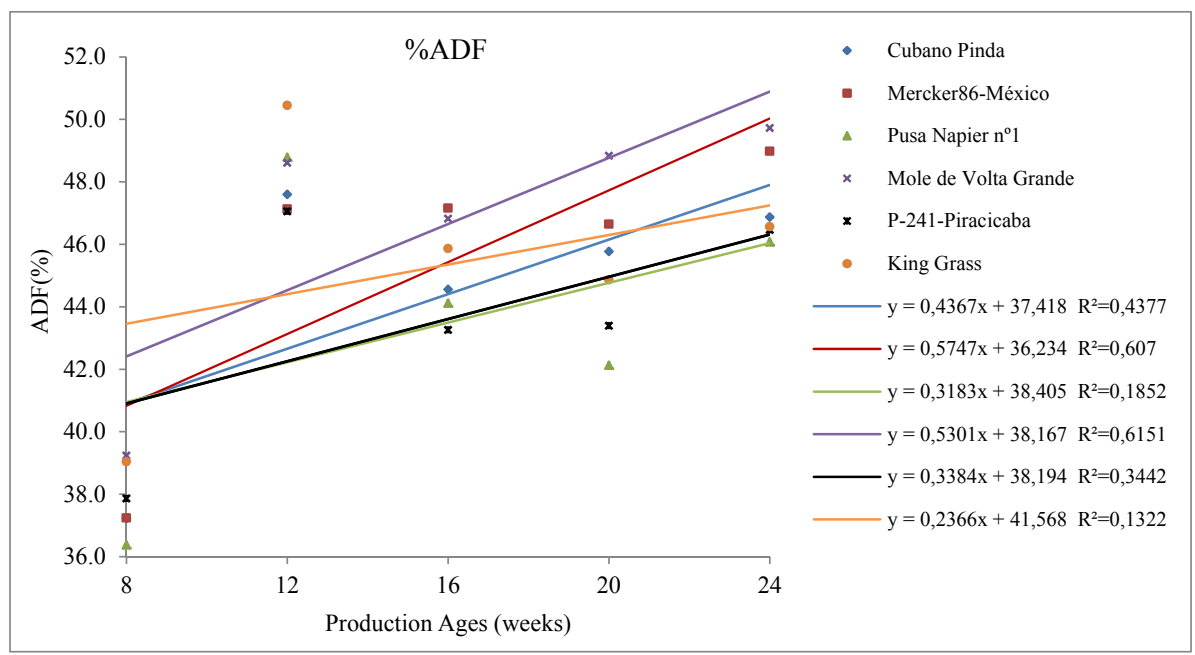

Figure 5. Lines adjusted for acid detergent fiber (ADF) obtained at five harvest times in genotypes Cubano Pinda

(1), Mercker 86-México (2), Pusa Napier n ${ }^{\circ} 1$ (3), Mole de Volta Grande (4), P-241-Piracicaba (5), and King

Grass (6)

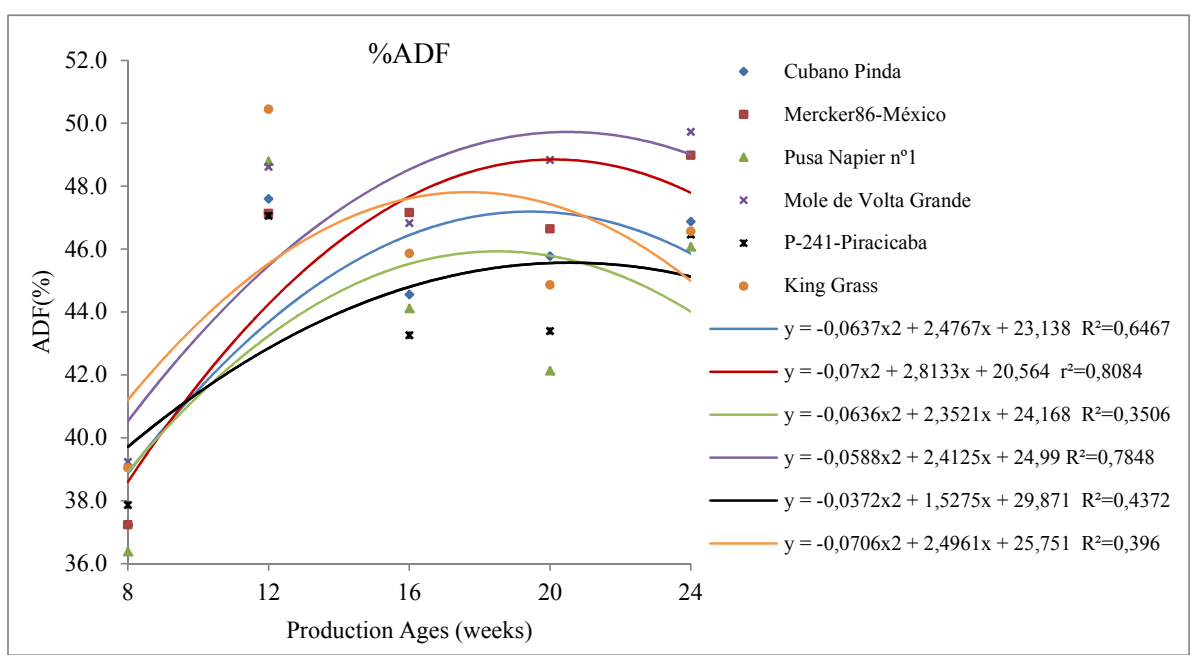

Figure 6. Curves adjusted for acid detergent fiber (ADF) obtained at five harvest times in genotypes Cubano Pinda (1), Mercker 86-México (2), Pusa Napier n⿳01 (3), Mole de Volta Grande (4), P-241-Piracicaba (5), and King Grass (6)

Queiroz Filho et al. (2000) investigated the biomass quality of different genotypes, at different harvest ages, and found an $\mathrm{ADF}$ content of $48 \%$ at 100 days of growth (whole-plant mean), which was close to the result found in the present study.

Morais et al. (2011) studied genotypes of elephant grass cultivated in a Planosol (Brazilian Soil Taxonomy) and found ADF values ranging from 34.4 and $42.1 \%$ for the stem and leaf fractions, respectively. These values are slightly lower than those found in the present study.

After this period, a decrease was observed in ADF, proving that the fiber contents in the plants are highly variable and can be influenced by several factors. Fava (2008) evaluated the ADF contents in the rainy and dry seasons in the Cerrado Matogrossense biome and obtained ADF contents of 48.2 and $45.8 \%$ in the respective periods, explaining the variability existing in fiber components. Soil-climatic conditions of the region, period of growth, and interval between harvests markedly influence the accumulation of these components in plant tissues.

The main obstacle in elephant grass production aimed at energy generation is determining the crop growing period, in which case longer harvest intervals lead to considerable increases in yield and mainly in fiber contents. Results for variables pertaining to the fiber content of the grass indicate that there is no need to maintain the 
material in the field for more than 20 weeks and that it can be used for biomass production at less than six months of age. However, further studies should be conducted on elephant grass during the dry season so that these numbers can be confirmed.

\section{Conclusions}

The genotypes Cubano de Pinda, Mercker 86-México and P-241-Piracicaba presented a significant linear first degree effect as a function of the cut intervals, indicating that they did not reach their maximum production potential. On the other hand, the genotypes Pusa Napier $n^{\circ} 1$, Mole de Volta Grande and King Grass, presented a linear effect of second degree.

For the NDF variable, all genotypes showed a significant second degree effect as a function of cut intervals, except for the P-241-Piracicaba genotype, which showed no regression. For this same genotype there was a significant linear first degree effect for the FDA variable.

In view of the obtained results, to associate quantity with quality of dry matter for energy-generation purposes, the best harvest age for the evaluated genotypes of elephant grass is 20 weeks.

\section{References}

Bhering, M., Cabral, L. S., Abreu, J. G., Souza, A. L., Zervoudakis, J. T., Rodrigues, R. S., ... Oliveira, I. S. (2008). Características agronômicas do capim-elefante Roxo em diferentes idades de corte na depressão Cuiabana. Revista Brasileira de Saúde e Produção Animal, 9, 384-396.

Cruz, C. D. (2013). GENES. A software package for analysis in experimental statistics and quantitative genetics. Acta Scientiarum Agronomy, 35, 271-276. https://doi.org/10.4025/actasciagron.v35i3.21251

EMBRAPA. (2006). Sistema brasileiro de classificação de solos (2nd ed.). Rio de Janeiro, Empresa Brasileira de Pesquisa Agropecuária Solos.

Fava, A. R. (2008). Avaliação de clones de capim-elefante (Pennisetum purpureum Schum.) para utilização em capineira no cerrado matogrossense (Unpublished dissertation, Universidade Federal de Mato Grosso).

Flores, R. A., Urquiaga, S., Alves, B. J. R., Collier, L. S., Zanetti, J. B., \& Prado, R. M. (2013). Nitrogênio e idade de corte na qualidade da biomassa de capim-elefante para fins agroenergéticos cultivado em Latossolo. Semina: Ciências Agrarias, 34, 127-136. https://doi.org/10.5433/1679-0359.2013v34n1p127

Fontoura, C. F. Brandão, L. E., \& Gomes, L. L. (2015). Elephant grass biorefineries: Towards a cleaner Brazilian energy matrix? Journal of Cleaner Production, 96, 85-93. https://doi.org/10.1016/j.jclepro.2014.02.062

IPCC (Intergovernmental Panel on Climate Change). (2011). IPCC Special Report on Renewable Energy Sources and Climate Change Mitigation.

Kalt, G., \& Kranzl, L. (2011). Assessing the economic efficiency of bioenergy technologies in climate mitigation and fossil fuel replacement in Austria using a techno-economic approach, Applied Energy, 88, 3665-3684. https://doi.org/10.1016/j.apenergy.2011.03.014

Köppen, W. (1948). Climatologia: con un estudio de los climas de la tierra. México D.F, Fondo de Cultura Econômica.

Leite, R. M. B., Queiroz Filho, J. L. de, \& Silva, D. S. (2000). Produção e valor nutritivo do capim-elefante cultivar Cameroon em diferentes idades. Agropecuária Técnica, 21, 30-39.

Magalhães, J. A., Lopes, E. A., Rodrigues, B. H. N., Costa, N. L., Barros, N. N., \& Mattei, D. A. (2006). Influência da adubação nitrogenada e da idade de corte sobre o rendimento forrageiro do capim-elefante. Revista Ciência Agronômica, 37, 91-96.

Martins-Costa, R. H. de A., Cabral, L. da S., Bhering, M., Abreu, J. G. de, Zervoudakis, J. T., Rodrigues, R. C., \& Oliveira, Í. S. de. (2008). Valor nutritivo do capim-elefante obtido em diferentes idades de corte. Revista Brasileira de Saúde e Produção Animal, 9, 397-406.

Mistura, C., Fonseca, D. M., Moreira, L. M., Fagundes, J. F., Morais, R. V., Queiroz, A. C., \& Ribeiro Júnior, J. I. (2007). Efeito da adubação nitrogenada e irrigação sobre a composição químico-bromatológica das lâminas foliares e da planta inteira de capim-elefante sob pastejo, Revista Brasileira de Zootecnia, 36, 1707-1714. https://doi.org/10.1590/S1516-35982007000800002

Mohammed, I. Y., Abakr, Y. A., Kazi, F. K., Yusup, S., Alshareef, I., \& Chin, S. A. (2015). Comprehensive Characterization of Napier Grass as a Feedstock for Thermochemical Conversion. Energies, 8, 3403-3417. https://doi.org/10.3390/en8053403 
Morais, R. F., Quesada, D. M., Reis, V. M., Urquiaga, S., Alves, B. J. R., \& Boddey, R. M. (2011). Contribution of biological nitrogen fixation to Elephant grass (Pennisetum purpureum Schum.). Plant and Soil, 349, 1-12. https://doi.org/10.1007/s11104-011-0944-2

Morais, R. F., Souza, B. J. de, Leite, J. M., Soares, L. H. de B., Alves, B. J. R., Boddey, R. M., \& Urquiaga, S. (2009). Elephant Grass genotypes for bioenergy production by direct biomass combustion. Pesquisa Agropecuária Brasileira, 44, 133-140. https://doi.org/10.1590/S0100-204X2009000200004

Pereira, A. V., Cruz, C. D., \& Ferreira, R. P. (2002). Influência da estabilização de genótipos de capim-elefante (Pennisetum purpureum Schum.) sobre a estimativa da repetibilidade de características forrageiras. Ciência e Agrotecnologia, 26, 762-767.

Queiroz Filho, J. L. de, Silva, D. V. da, \& Nascimento, I. S. (2000). Produção de matéria seca e qualidade do capim-elefante (Pennisetum purpureum Schum.) cultivar Roxo em diferentes idades de corte. Revista Brasileira de Zootecnia, 29, 69-74. https://doi.org/10.1590/S1516-35982000000100010

Quitete, V. R. S. (2011). Dialelo parcial em capim-elefante: Capacidade combinatória em caracteres morfoagronômicos e bromatológicos em Campos Dos Goytacazes, RJ. (Unpublished doctoral dissertation, Universidade Estadual do Norte/Fluminense Darcy Ribeiro, UENF).

Rossi, D. A., Menezes, B. R. S., Daher, R. F., Gravina, G. A., Lima, R. S. N., Ledo, F. J. S., ... Souza, C. L. M. (2014). Canonical correlations in elephant grass for energy purposes. African Journal of Biotechnology, 13, 3666-3671. https://doi.org/10.5897/AJB2014.13915

Sales, F. A., Caramori, P. H., Ricce, W. S., Costa, M. A. T., \& Zaro, G. C. (2015). Biomass of elephant grass and leucaena for bioenergy production. Semina: Ciências Agrárias, 36, 3567-3578. https://doi.org/10.5433/ 1679-0359.2015v36n6p3567

Scarlat, N., Dallemanda, J., Skjelhaugenb, O. J., Asplundc, D., \& Nesheim, L. (2011). An overview of the biomass resource potential of Norway for bioenergy use. Renewable and Sustainable Energy Reviews, 15, 3388-3398. https://doi.org/10.1016/j.rser.2011.04.028

Schemer, M. R., Vogel, K. P., Mitchell, R. B., \& Perrin, R. K. (2008). Net energy of cellulosic ethanol from switch grass. PNAS: National Acad Sciences, 105, 464-469. https://doi.org/10.1073/pnas.0704767105

Silva, A. L. C., Santos, M. V. F., Dubeux Júnior, J. C. B., Lira, M. A., Ferreira, L. R. C., Freitas, E. V., ... Silva, M. C. (2010). Variabilidade e herdabilidade de caracteres morfológicos em clones de capim-elefante na Zona da Mata de Pernambuco. Revista Brasileira de Zootecnia, 39, 2132-2140. https://doi.org/10.1590/ S1516-35982010001000005

Teixeira Vitor, C. M., Fonseca, D. M., Cóser, A. C., Martins, C. E., Nascimento Júnior, D., \& Ribeiro Júnior, J. I. (2009). Produção de matéria seca e valor nutritivo de pastagem de capim-elefante sob irrigação e adubação nitrogenada. Revista Brasileira Zootecnia, 38, 435-442. https://doi.org/10.1590/S1516-35982009000 300006

\section{Copyrights}

Copyright for this article is retained by the author(s), with first publication rights granted to the journal.

This is an open-access article distributed under the terms and conditions of the Creative Commons Attribution license (http://creativecommons.org/licenses/by/4.0/). 